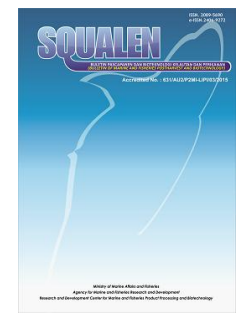

\title{
EFFECT OF AGITATION SPEED AND CULTIVATION TIME ON THE PRODUCTION OF THE EMESTRIN PRODUCED BY Emericella nidulans MARINE FUNGAL
}

\author{
Muhammad Nursid ${ }^{1}$, Martua Manulang' ${ }^{2}$, Joko Samiadji' ${ }^{2}$, and Endar Marraskuranto ${ }^{1}$ \\ ${ }^{1}$ Research and Development Center for Marine and Fisheries Product Processing and Biotehnology, \\ Jalan KS. Tubun Petamburan VI, Slipi, Central Jakarta 10260, Indonesia; \\ ${ }^{2}$ Faculty of Fisheries and Marine Science, University of Riau, Pekanbaru \\ Article history: \\ Received: 2 May 2015; Revised: 28 May 2015; Accepted: 10 June 2015
}

\begin{abstract}
Emestrin, an epipolythidioxopiperazine (EPT), is bioactive secondary metabolite produced by the marine fungus Emericella nidulans. Emestrin is potential to be developed as anticancer agent. Our present study investigated the effect of the agitation speed and cultivation time on the production of the mycelial biomass and emestrin in $E$. nidulans. The fungal was cultivated in malt extract broth (MEB) medium with varying agitation speeds of $0,50,100$, $150 \mathrm{rpm}$ during $1,2,3$ and 4 weeks of incubation at the temperature of $28{ }^{\circ} \mathrm{C}$. Concentration of emestrin was determined by using high performed liquid chromatography (HPLC). The highest concentration of emestrin was found at static condition ( 0 rpm) cultivated for 1 week.
\end{abstract}

Keywords: emericella nidulands, emestrin, agitation speed, culvation time

\section{Introduction}

Marine-derived fungi have been intensively explored for their bioactive secondary metabolites. Fungal metabolites exhibited diverse biological activities such as anticancer, antimicrobial, antiplasmodial, antiinflammatory and antiviral agents (Xiong et al., 2009; Ingavat et al., 2011). One of marine-derived fungi that produce bioactive secondary metabolites is $E$. nidulans. In our research works this fungal species was isolated from the surface of marine ascidian Aplidium longithorax collected from Wakatobi Marine National Park, Southeast Sulawesi, Indonesia. Static culture of this fungus in MEB produced emestrin (Figure 1). The molecular weight of emestrin was $597.1105[\mathrm{M}-\mathrm{H}]^{-}$. Emestrin displayed anticancer activity against several cancer cell lines (Nursid et al., 2011; 2015).

Emestrin is a member of epipoly thiodioxo piperazines (ETPs) that belongs to a group of toxic secondary metabolites made only by fungi (Gardiner et al., 2005; Jiang \& Guo, 2011). Emestrin A and B were originally isolated from the mycelial acetone extract of Emericella striata (Seya et al., 1985; Nozawa et al., 1987). Emestrin A, the first reported example of 15-membered macrocyclic ETP with strong antifungal activity, was biosynthetically derived from two molecules of phenylalanine and one molecule of benzoic acid (Jiang \& Guo, 2011).

Submerged cultures of filamentous fungi are widely used to produce commercially important metabolites including many antibiotics and the cholesterol lowering drugs (statins) such as lovastatin $\left(\mathrm{C}_{24} \mathrm{H}_{36} \mathrm{O}_{5}\right.$, Mevinolin, Monacolin $\mathrm{K}$ and Mevacor ${ }^{\mathrm{TM}}$ ). In submerged cultures, fungi can be grown as broths of freely suspended mycelia and pellets or clumps (Metz \& Kossen, 1977). In our previous study (Nursid et al., 2012), optimal media for emestrin production was MEB containing malt extract, yeast extract, and soya peptone. Production of secondary metabolites in sub merged cultures is influenced by many factors such as agitation and time of cultivation. Agitation is an important parameter for mixing the nutrient, mass and heat transfer. Agitation makes shear forces, causing

${ }^{*}$ Corresponding author.

E-mail: mnursid@kkp.go.id 


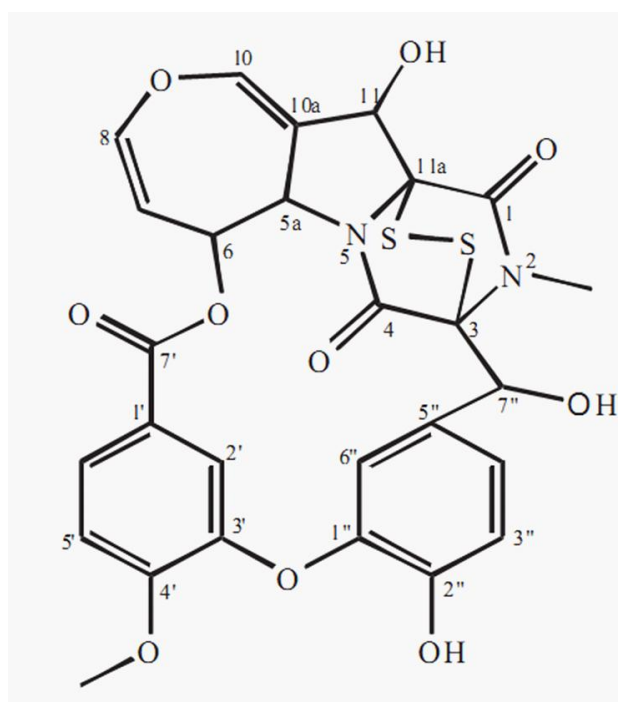

Figure 1. Chemical structure of emestrin.

morphological changes, variation in their growth and product formation, and also damage to the cell structure (Kim et al., 2003).

The purpose of this study was to determine the effects of agitation speed and cultivation time on the mycelial biomass and emestrin production by $E$. nidulans in submerged culture. The morphological features between the different agitation speed were also described.

\section{Material and Methods}

\subsection{Fungal Material}

E. nidulans was from a culture collection of Biotechnology Laboratory, Research and Development Center for Marine and Fisheries Product Processing and Biotechnology, Jakarta, Indonesia. This strain was isolated from the surface of marine ascidia $A$. longithorax collected from Wakatobi Marine National Park, Southeast Sulawesi, Indonesia. The stock culture was preserved in the mixture of $20 \%$ glycerol and $80 \%$ malt exract agar $(\mathrm{v} / \mathrm{v})$ and stored in deep freezer at $-80^{\circ} \mathrm{C}$.

\subsection{Fungal Cultivation}

E. nidulans was initially grown on malt extract agar (MEA) medium in a petri dish and then transferred to the seed culture medium by punching out $5 \mathrm{~mm}$ of the agar plate culture with a sterilized cutter. The seed culture was grown in a $250 \mathrm{ml}$ flask containing 100 $\mathrm{ml}$ MEB medium consisting of $3 \mathrm{~g}$ yeast extract, $3 \mathrm{~g}$ malt extract, $5 \mathrm{~g}$ peptone, in sea water with salinity of $10 \mathrm{ppt}$ ). The cultures were agitated at $0 \mathrm{rpm}, 50,100$, and $150 \mathrm{rpm}$ for $1,2,3$, and 4 weeks at the temperature of $28^{\circ} \mathrm{C}$. All experiment were performed in triplicate.

\subsection{Extraction}

Mycelium harvested from the culture and filtered with filter paper (Whatman no. 41). Fungal mycelium dried by using freeze-drying then weighed. Extraction of secondary metabolites from dried mycelium was carried out by using $50 \mathrm{ml}$ of methanol $(\mathrm{MeOH})$ : methylen chloride $\left(\mathrm{CHCl}_{2}\right)(1: 1, \mathrm{v} / \mathrm{v})$ three times. Extraction of secondary metabolites from broth culture was performed three times with ethyl acetate $(3 \mathrm{x}$ $100 \mathrm{ml}$ ). The $\mathrm{MeOH}-\mathrm{CHCl}_{2}$ and combined EtOAc solution was concentrated by vaccum rotary evaporator and dried by using vaccum concentrator. Mycelium and broth crude extracts was weighed to obtain the yield.

\subsection{Analysis of Emestrin}

Analysis of emestrin in the mycelium and broth extract was carried out by using high performance liquid chromatography (HPLC, Shimadzu). The HPLC condition was set up as follows: mobile phase was acetonitrile $15 \%$ in water (gradient 40 minutes), $C_{18}$ column $150 \times 2.0 \mathrm{~mm}$ (Phenomenex), photo diode array (PDA) detector; column temperature was $30^{\circ} \mathrm{C}$; injection volume was $10 \mu \mathrm{l}$ with flowrate was $0.2 \mathrm{ml} /$ minutes. Emestrin concentration was calculated with standard curve of emestrin in $\mu \mathrm{g} / \mathrm{g}$ crude extract.

\section{Result and Discussion}

\subsection{Pellet Morphology}

Agitation speed of liquid culture of E. nidulans caused differences in mycelium morphology. At the agitation speed of $50 \mathrm{rpm}$, mycelium of $E$. nidulans remains on the surface of medium, only a little 

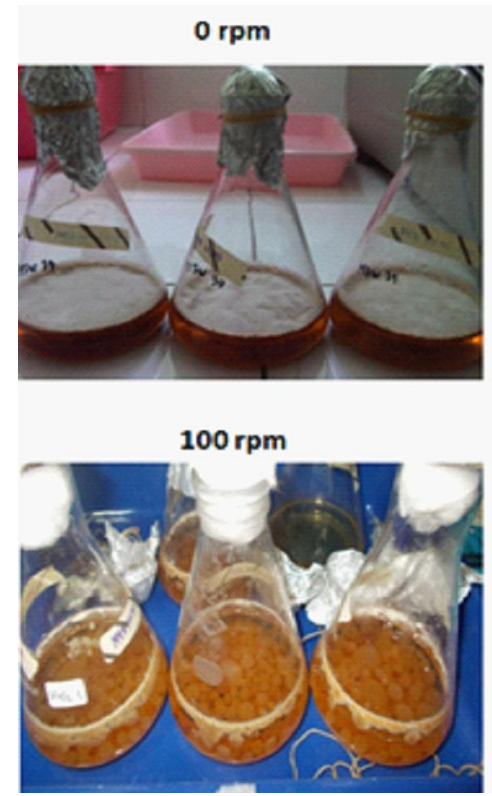

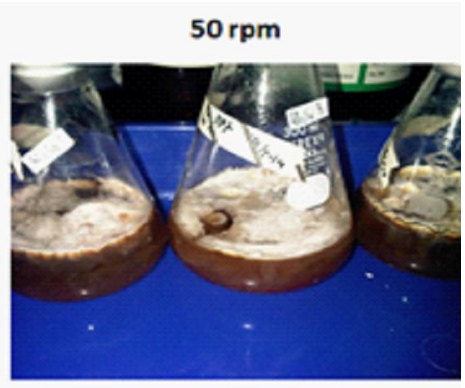

$150 \mathrm{rpm}$

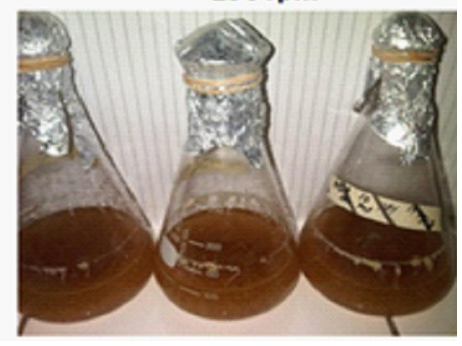

Figure 2. Mycelium morphology of $E$. nidulans cultivated at $0,50,100$, and $150 \mathrm{rpm}$ agitation speed.

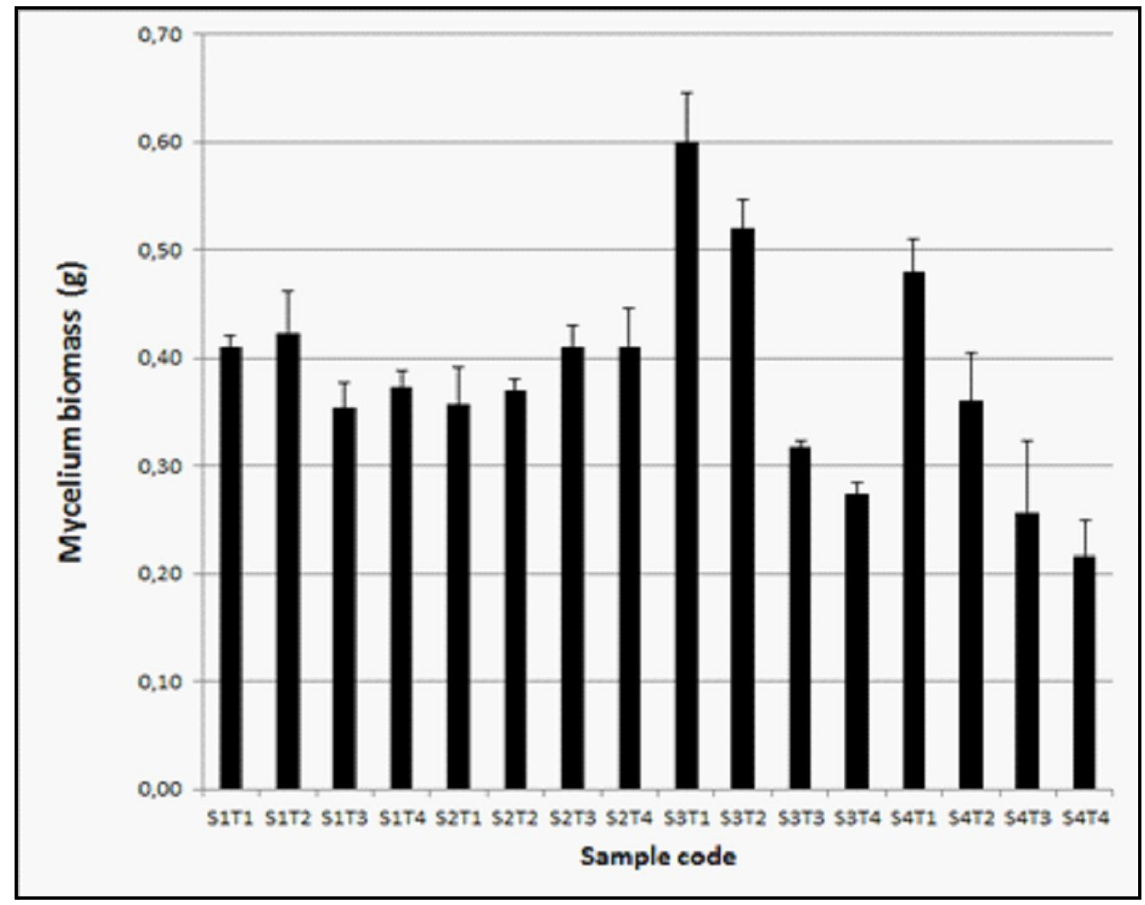

Figure 3. Effect of agitation speed and cultivation time on mycelium biomass ( \pm standard deviation)

Note: S1T1: $0 \mathrm{rpm} 1$ week, S1T2 $=0 \mathrm{rpm} 2$ weeks, S1T3 $=0 \mathrm{rpm} 3$ weeks, S1T4 $=0 \mathrm{rpm} 4$ weeks, S2T1 = $50 \mathrm{rpm} 1$ week, S2T2 $=50 \mathrm{rpm} 2$ weeks, S2T3 $=50 \mathrm{rpm} 3$ weeks, S2T4 $=50 \mathrm{rpm} 4$ weeks, S3T1 = $100 \mathrm{rpm} 1$ week, S3T2 $=100 \mathrm{rpm} 2$ weeks, S3T3 $=100 \mathrm{rpm} 3$ weeks, S3T4 $=100 \mathrm{rpm} 4$ weeks, S4T1 $=150 \mathrm{rpm} 1$ weeks, S4T2, $150 \mathrm{rpm} 2$ weeks, S4T3 $=150 \mathrm{rpm} 3$ weeks, S4T4 = $150 \mathrm{rpm} 4$ weeks.

mycelium submerged in the culture media. In this state, mycelium still sporulated on the surface of medium. However, at agitation speed of 100 and $150 \mathrm{rpm}$, mycelium morphology transformed into spherical and submerged in the culture media. Diameter of pellets at $100 \mathrm{rpm}$ were $40-60 \mathrm{~mm}$ whereas pellets diameter at $150 \mathrm{rpm}$ were smaller $(10-20 \mathrm{~mm})$. In static condition $(0 \mathrm{rpm})$, all mycelium sporulated on the surface (Figure 2). The specific growth morphology of fungal mycelium obtained under given conditions 
depends on several factors including the fungal strain, the method of initiation of culture (e.g. spores, pellets, dispersed mycelium), the nature of the growth medium, and the hydrodynamic regime in the bioreactor (Lopez et al., 2005). There was a significant correlation between the speed of agitation and morphology hypa including tannase enzyme production (Purwanto et al., 2009). In the production of exopolysaccharide from Grifola fondosan fungi, mycelium morphology was greatly influenced by $\mathrm{pH}$, aeration and hydrodynamic conditions during fermentation process (Lee et al. 2004).

The highest mycelial biomass was obtained from cultivation using the agitation speed of $100 \mathrm{rpm}$ for one week and the lowest was using agitation treatment of $200 \mathrm{rpm}$ for four weeks (Figure 3). The former was likely due to the optimum nurient and oxygen distribution in the flask, however, at speed of $150 \mathrm{rpm}$, biomass growth (pellet) was disturbed by shear forces. Agitation intensity was a critical point influencing biomass production (Kim et al., 2003). Agitation resulted in a better contact with air (namely oxygen) in order to increase biomass (Noraziah \& Izyani, 2012). Aspergilus niger mycelial growth optimally at the agitation speed of $100 \mathrm{rpm}$, however tanase production optimally occured at the speed of $130 \mathrm{rpm}$ (Purwanto et al., 2009). Mycelial growth depends on nutrient availability in the media. Starch, sucrose, maltose, glucose, and galactose are the carbon sources that are often used in submerged culture, while pepton is the nitrogen source.

\subsection{Emestrin Detection and Concentration}

Emestrin concentration was detected by HPLC based on the resulting peak retention time and UV characteristics. Emestrin had been isolated from the previous work (Nursid et al., 2011). In that work, standard emestrin was detected at $17.302 \mathrm{~min}$ (Figure. 4). Detection of emestrin was also conducted based on the UV absorption of the emestrin at $\lambda_{\max } 202 \mathrm{~nm}$. Based on the retention time and UV characteristics, emestrin was detected in the mycelial extract.

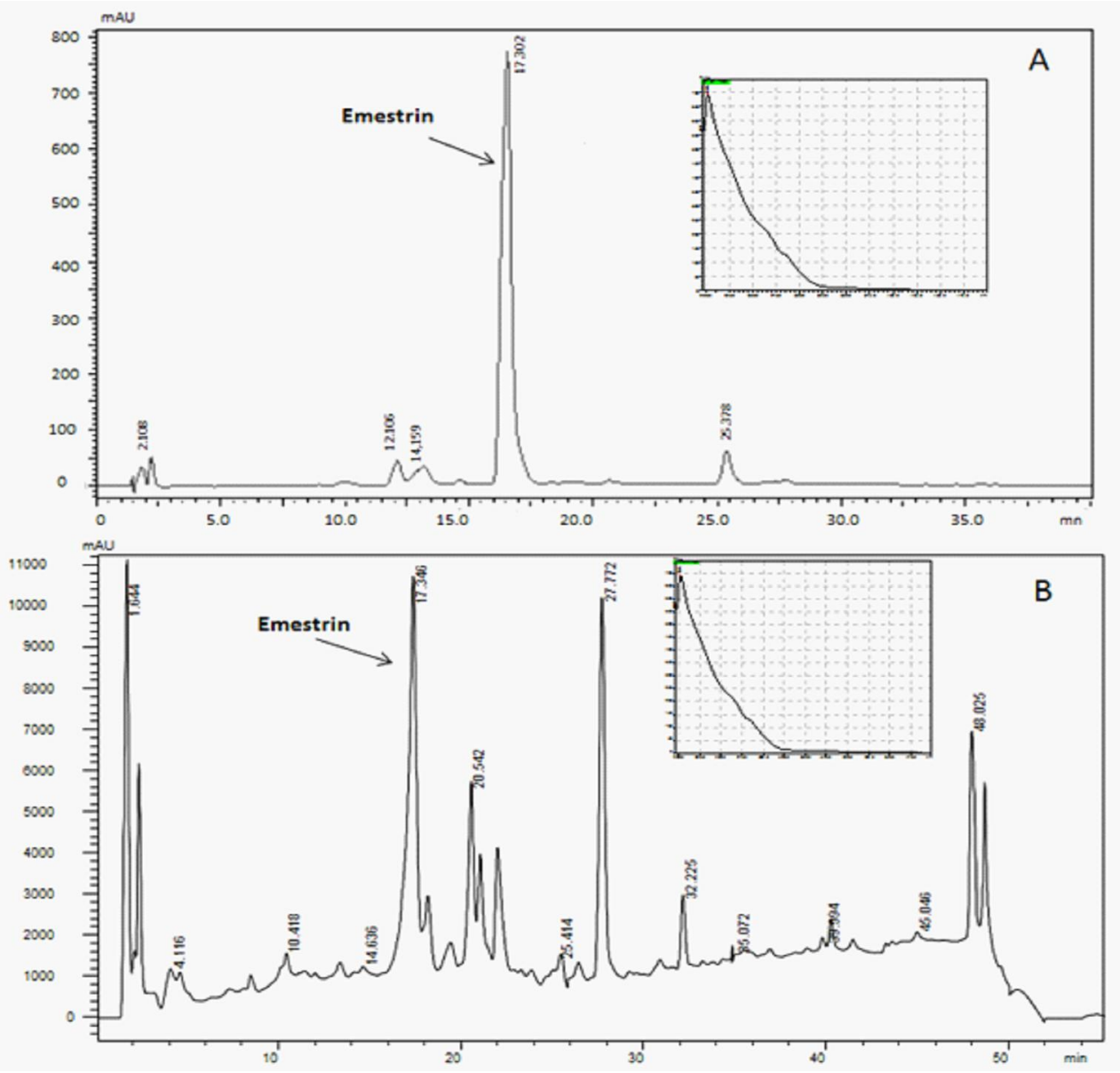

Figure 4. Emestrin standard chromatogram (A, insert: emestrin UV absorption) and emestrin contained mycelial crude extract chromatogram (B). 


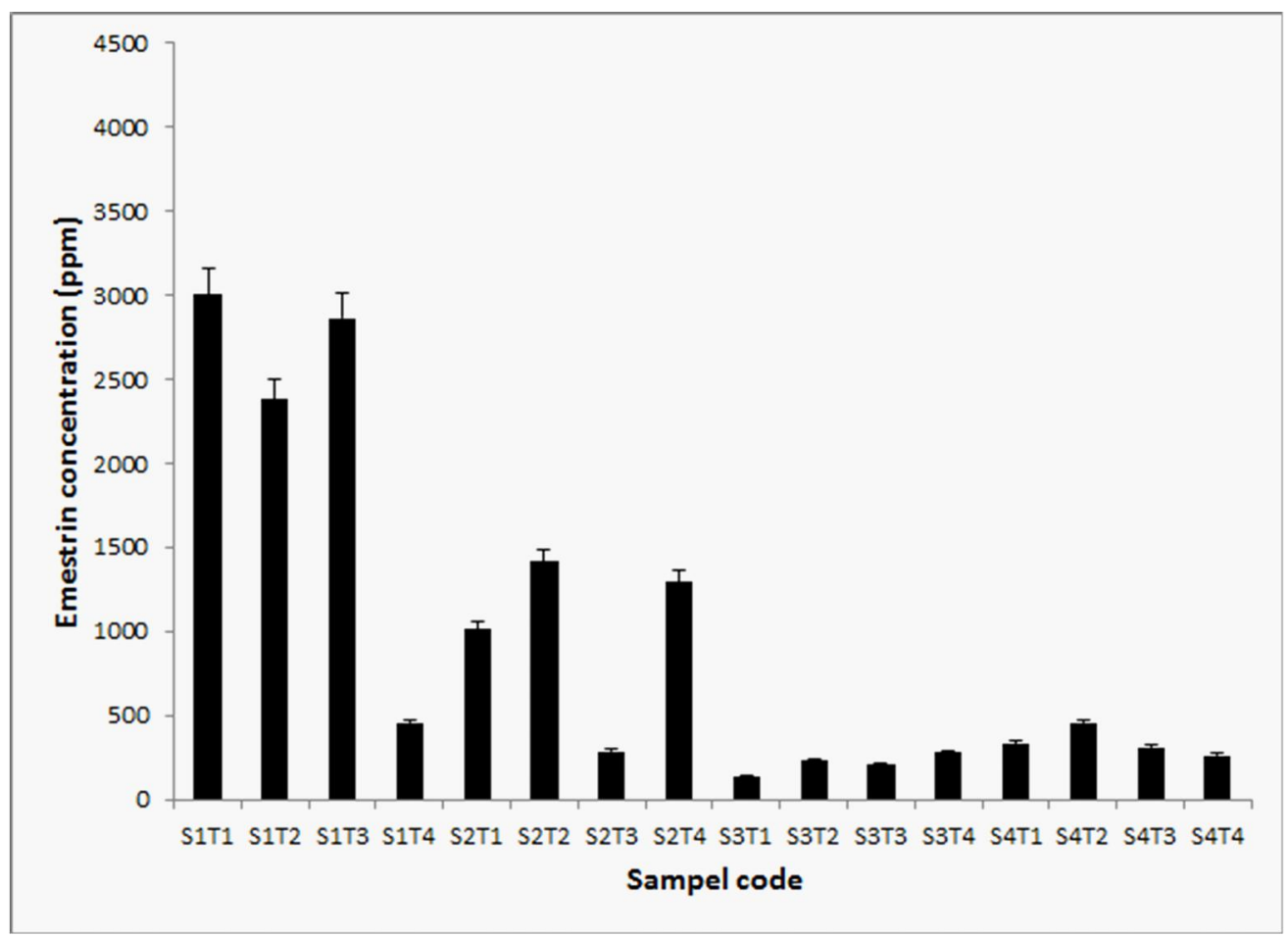

Figure 5. Emestrin concentration in the mycelium extract ( \pm standard deviation).

Note: S1T1: 0 rpm 1 week, S1T2 $=0$ rpm 2 weeks, S1T3 $=0$ rpm 3 weeks, S1T4 $=0$ rpm 4 weeks, S2T1 = $50 \mathrm{rpm} 1$ week, S2T2 $=50 \mathrm{rpm} 2$ weeks, S2T3 $=50 \mathrm{rpm} 3$ weeks, S2T4 $=50 \mathrm{rpm} 4$ weeks, S3T1 = $100 \mathrm{rpm} 1$ week, S3T2 $=100 \mathrm{rpm} 2$ weeks, S3T3 $=100 \mathrm{rpm} 3$ weeks, S3T4 $=100 \mathrm{rpm} 4$ weeks, S4T1 $=150 \mathrm{rpm} 1$ weeks, S4T2, $150 \mathrm{rpm} 2$ weeks, S4T3 $=150 \mathrm{rpm} 3$ weeks, S4T4 = $150 \mathrm{rpm} 4$ weeks.

According to the emestrin standard curve, we calculated emestrin concentration in every agitation speed and cultivation time treatment. The highest emestrin concentration was obtained from $E$. nidulans mycelial that was cultivated at static condition (without agitation) (Figure. 5) and followed by agitation treatment of $50 \mathrm{rpm}$.

The highest emestrin concentration was obtained in the static condition, while the highest biomass was obtained in agitated culture at $100 \mathrm{rpm}$ for one week. The result showed that emestrin production does not depend on biomass quantity. Some active compound resulted from explorative study on fungi was produced in static condition. Anti-leukemia active compound of sorbicilactone was produced in lab scale from a static cultur of Penicillium chrysogenum (Bringmann et al., 2007). So it was with cytotoxic compound of scopularide that was produced static culture of fungi Scopulariopsis brevicaulis (Tamminen et al., 2014). Our results suggested that, for emestrin production in large scale, it is necessary to improve culture conditions, such as mixing, aeration, and nutrient source optimation. Therefore, in certain level, agitation is needed for emestrin production in large scale.

Generally, in submerged cultures, it is necessary to agitate the culture broth in order to obtain good mixing and thereby promote heat and mass transfer (Gong \& Zhong, 2005). However, agitation also creates shear force. The shear stress exerted by the impeller blades in an agitated fermenter usually reduces and modifies the mycelium pellet growth in terms of diameter, circularity and compactness, and the accumulation of metabolites (Liu et al., 2012).

\section{Conclusion}

The highest mycelial biomass of the marine fungus E.nidulans was obtained from cultivation using agitation speed of $100 \mathrm{rpm}$ for one week, while the highest emestrin concentration was obtained in the static fungal culture.

\section{Acknowledgment}

This research was funded by National Budget (APBN) granted to Ministry of Marine and Fisheries Affairs, Republic of Indonesia.

\section{References}

Bringmann, G., Gulder, T.A.M., Lang, G., Schmitt, S., Stohr, R., Wiese, J., Nagel, K., \& Imhoff, F. (2007). Largescale biotechnological production of the antileukemic marine natural product sorbicillactone A. Marine Drugs, 5: 23-30. 
Gardiner, D.M., Waring, P., \& Howlett, B.J. (2005). The Epipolythiodioxopiperazine (ETP) class of fungal toxins: distribution, mode of action, functions and biosynthesis. Microbiology, 151: 1021-1032.

Gong, H.G., \& Zhong, J.J. (2005). Hydrodynamic shear stress affects cell growth and metabolite production by medicinal mushroom Ganoderma lucidum. Chin. J.Chem. Eng., 13: 426-428.

Jiang, C.S., \& Guo, Y.W. (2011). Epipolythiodioxopiperazines from fungi: chemistry and bioactivities. Mini-Reviews in Medicinal Chemistry, 11: 728-745

Kim, S.W., Hwang, H.J., Xu, C.P., Choi, J.W., \& Yun, J.W. (2003). Effect of aeration and agitation on the production of mycelial biomass and exopolysaccharides in an enthomopathogenic fungus Paecilomyces sinclairii. Letters in Applied Microbiology, 36: 321-326.

Liu, Q.Q., Wang X.L., Han, W.J., \& Lin, Q.L. (2012). Improving the fermentation production of the individual key triterpene ganoderic acid me by the Medicinal Fungus Ganoderma lucidumin Submerged Culture. Molecules, 17: 12575-12586.

Lee, B.C., Bae, J.T., Pyo, H.B., Choe, T.B., Kim, S.W., \& Yunc, J.J. (2004). Submerged culture conditions for the production of mycelial biomass and exopolysaccharides by the edible Basidiomycete Grifola frondosa. Enzyme and Microbial Technology, 35: 369-376.

Lopez, J.L.C., Perez, J.A.S., Sevilla, J.M.F., Porcel, E.M.R., \& Chisti, Y. (2005). Pellet morphology, culture rheology and lovastatin production in cultures of Aspergillus terreus. Journal of Biotechnology, 116: 61 - 77.

Ingavat, N., Mahidol, C., Ruchirawat, S., \& Kittakoop, P. (2011). Asperaculin A, a sesquiterpenoid from a marine-derived fungus, Aspergillus aculeatus. Journal of Natural Product, 74: 1650 - 1652.

Metz, B., \& Kossen, N.W.F. (1977). The growth of molds in the form of pellets, a literature review. Biotechnology and Bioengineering., 19: 781-799

Noraziah, A.Y., \& Nurul Izyani, A.M. (2012). Influence of carbon source and culture condition on arachidonic acid production by Candida krusei in submerged culture. $2^{\text {nd }}$ International Conference on Chemical, Biological and Environment Sciences (ICCEBS'2012) June 30-July 1, 2012 Bali: 32-35.

Nozawa, K., Udagawa, S., Nakajima, S., \& Kawai, K. (1987). Studies on fungal products : XIV, Emestrin B, a new ETP, from Emericella striata. Chemical and Pharmacy Bulletin, 35(8), 3460-3461.

Nursid, M., Chasanah, E., Murwantoko, \& Wahyuono, S. (2011). Isolation and identification of emestrin from Emericella nidulans and investigation of its anticancer properties. Microbiology Indonesia, 5 (4):160-169.

Nursid, M., Fajarningsih, N.D., Marraskuranto, E., Sujuliyani \& Chasanah, E. (2012). Concentration of emestrin from Emericella nidulans cultivated in different medium and cultivation time. Journal of Marine and Fiheries Post Harvest and Biotechnology, 7 (2) : 77 - 86.

Nursid, M., Namirah, I., Cahyana, A.H., Fajarningsih, N.D. and Chasanah. (2015). Emestrin B: epipolythiodioxypiperazine from marine derived fungus Emericella nidulans. Journal of Medical and Bioengineering, 4 (6): 441-445.

Purwanto, L., Ibrahim, D., \& Sudrajat, H. (2009). Effect of agitation speed on morphological changes in Aspergillus niger hyphae during production of tannase. World Journal of Chemistry, 4 (1): 34-38.

Seya, K., Nakajima, S., \& Kawai, K. (1985). Structure and absolute configuration of emestrin, a new macrocyclic epidithiodioxopiperazine from Emericella striata. Journal of Chemical Socialization and Chemical Community, 117: 657-658

Tamminen, A., Kramer, A., Labes, A., \& Wiebe, M.G. (2014). Production of scopularide $A$ in submerged culture with Scopulariopsis brevicaulis. Microbial Cell Factories, 13: 1 - 7.

Xiong, H., Qi, S., Xu, Y., \& Qian, P.Y. (2009). Antibiotic and antifouling compound production by the marinederived fungus Cladosporium sp. F14. Journal of Hydro-environment Research, 2: 264 - 270. 